given over long periods without habit formation, the dose being regulated according to the effect. A proprietary form of standardized senna is available in tablets or chocolatecoated granules and is taken well by children. In the more severe cases where the intestine contains hard lumps of faeces and there is a long history of constipation the bowel must be thoroughly emptied, if necessary manually, and then a course of colonic wash-outs instituted, at first daily for one or two weeks and then at decreasing intervals until the sensitivity of the bowel to filling has returned and spontaneous evacuations take place. An aperient, of which senna or neostigmine-neostigmine bromide, $10 \mathrm{mg}$., magnesium sulphate, $20 \mathrm{gr}$. $(1.3 \mathrm{~g}$.), liquid paraffin emulsion, $30 \mathrm{~min}$. $(1.7 \mathrm{ml}$.), and chloroform water to make 2 drachms (7 ml.) : 2 to 4 drachms ( 7 to $14 \mathrm{ml}$.) as required, morning and evening before meals - seems the most effective, should be given as well and continued for some months and then gradually tailed off.

In many severe cases it will be found that there is a considerable psychological element, and serious emotional disturbance in the family, for which some advice will be necessary. It must be admitted that in the worst cases treatment is unsatisfactory and relapses very common, although the results are excellent in the less severe.

\section{Treatment of Sonne Dysentery}

Q. -What is the best treatment for Sonne dysentery? Should the classical treatment of purging with castor oil and salts be abandoned?

A. - Soluble or "insoluble" sulphonamides may be given. The latter are generally preferred, although the formerparticularly in America-are quite often used for this purpose. There is evidence that phthalyl sulphathiazole is the most active sulphonamide in Bacillus dysenteriae (Sonne) infections; the adult dosage recommended is $3 \mathrm{~g}$. 4-hourly until fewer than five stools are passed per day, and thereafter the same amount 8-hourly until there has been no diarrhoea for 2 days or until 12 days have elapsed. Succinyl sulphathiazole or sulphaguanidine may be used in doses of $7 \mathrm{~g}$ and $3.5 \mathrm{~g}$. respectively in an otherwise unchanged regime It is important that dehydration should be prevented or corrected if present. The frequency with which it occurs in dysentery, and the consequent risk of crystals being deposited in the urinary tract, constitute important reasons for avoiding the use of soluble sulphonamides when dealing with cases of this kind in warm climates.

The results of treatment of dysentery with sulphonamides are so much better than those following the use of purgatives that the latter should no longer be used for this purpose.

\section{Yew Poisoning}

Q.-A patient when cooking Brussels sprouts found a sprig of yew had been boiled with them. Having lost a horse allegedly from eating yew, she asked my advice, which was not to eat the sprouts. If she had done so, could any harm have resulted?

A. - The leaves, shoots, and fruit of the yew (Taxus baccata) contain an alkaloid, taxine, of unknown structure, which is highly toxic; the lethal intravenous dose for rabbits is $2-3 \mathrm{mg}$. per $\mathrm{kg}$., and for mice and guinea-pigs $12 \mathrm{mg}$. per $\mathrm{kg}$., death being due to cardiac and respiratory failure. The earliest symptom of taxine poisoning in man after eating yew is gastro-intestinal irritation and vomiting. Taxine is described as being insoluble in water though readily soluble in acid solution. It is possible that vegetables cooked with a sprig of yew might be sufficiently contaminated with the alkaloid to cause unpleasant gastrointestinal disturbance.

Bryan-Brown, ${ }^{1}$ in an excellent paper on the pharmacology of taxine, states that many cases of yew poisoning in man were recorded in the eighteenth and nineteenth century, and that horses and cattle have often succumbed as a result of eating yew. He cites 24 references to cases of yew poisoning in man, and 12 on yew poisoning in horses and cattle.
He also says in his paper: "It seems fairly well established that taxine is present in large quantities only in the old leaves and in the seeds. The pulp of the berries contains practically none and can be eaten with impunity. This seems to explain why there are found among the accounts of the older writers such contradictory views about the poisonous nature of yew berries." Perhaps this has also a bearing on W. H. Hudson's observation (in Nature in Downland) that missel thrushes gorge themselves with yew berries, which they then disgorge, returning to gorge themselves again.

REFERENCE

1 Bryan-Brown, 'T., Quart. J. Pharm., 1932, 5, 205.

\section{Corneal Dystrophy}

Q.-What is the aetiology and treatment of corneal dystrophy? In particular, is vitamin lack a factor and is corneal transplantation ever indicated? What is the prognosis?

A.- Until Bückler's classification of corneal dystrophy in 1938 there was much confusion in the description of this disorder in the literature. To-day classification is based mainly on the morphological appearances and the layers of the cornea which are involved. The three commoner types of this rare disorder-(1) granular (crumb-like opacities), (2) macular (spotty), (3) reticular (lattice)-all have certain features in common in being familial and hereditary; the granular and reticular types are dominant, while the macular is recessive. Both eyes are affected, the disease begins in the first decade of life and is fairly symmetrical in disposition, there is no vascularization, and the centre of the cornea is first affected leaving a clear periphery between this and the limbus. The aetiology is unknown, and these forms of corneal dystrophy are resistant to any form of medical treatment.

In the case of macular dystrophy some surgeons have claimed good results from incising superficial nodules with a cataract knife and curetting them, or excising them with a small trephine. Corneal grafting is successful sometimes in these three types, but it often fails in Fuchs's epithelialendothelial hereditary dystrophy; indeed, in this type of dystrophy any form of intraocular surgery gives poor results. The pain associated with corneal dystrophy is often intractable and difficult to relieve. Superior petrosal neurectomy has eased it in some cases.

Also classified as dystrophies are lipoid and calcareous infiltrations of the cornea, transverse bands, protruding ringshaped opacities, and deep punctiform spots. Although these are reported to be unfavourable for keratoplasty, both lamellar and penetrating grafts may sometimes remain clear.

There is no evidence that vitamin lack is an aetiological factor in corneal dystrophy. The prognosis is bad in Fuchs's epithelial-endothelial dystrophy. Although the other types of dystrophy are progressive, some have periods of quiescence and inactivity during which the course of the disease may be halted.

Corrections.-In last week's Journal (p. 1102) we mistakenly referred to Dr. W. H. Dunlop as the first medical officer of health, instead of Dr. W. H. DuncaN.

In the Journal of April 28, p. 942, it should have been stated that methylpentynol is included in Schedule 1 of the Poisons Rules (not Schedule 4).

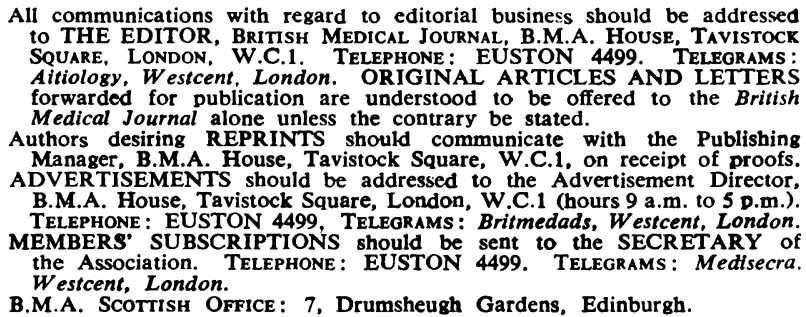

communications with regard to editorial business should be addressed TO THE EDITOR, BRITISH MEDICAL JOURNAL, B.M.A. HOUSE, TAVISTOCK Aitiology WEN, W.1. TELERIGE: EUSTON 4499. TELEGAMS : forward, festcent, London. ORIGINAL ARTICLES AND LET British Altiology

Authors desiring REPRINTS should communicate with the Publishing Manager, B.M.A. House, Tavistock Square, W.C.1, on receipt of proofs. DVERTISEMENTS should be addressed to the Advertisement Director, TELEPHONE: EUSTON 4499 Trieraus: Britmedads, Westcent London. EMBERS' SUBSCRIPTIONS should be sent to the SECRETARY of Westcent, London.

B.M.A. Scotrish Office: 7, Drumsheugh Gardens, Edinburgh. 